Alfalfa production

and management

in Atlantic Canada

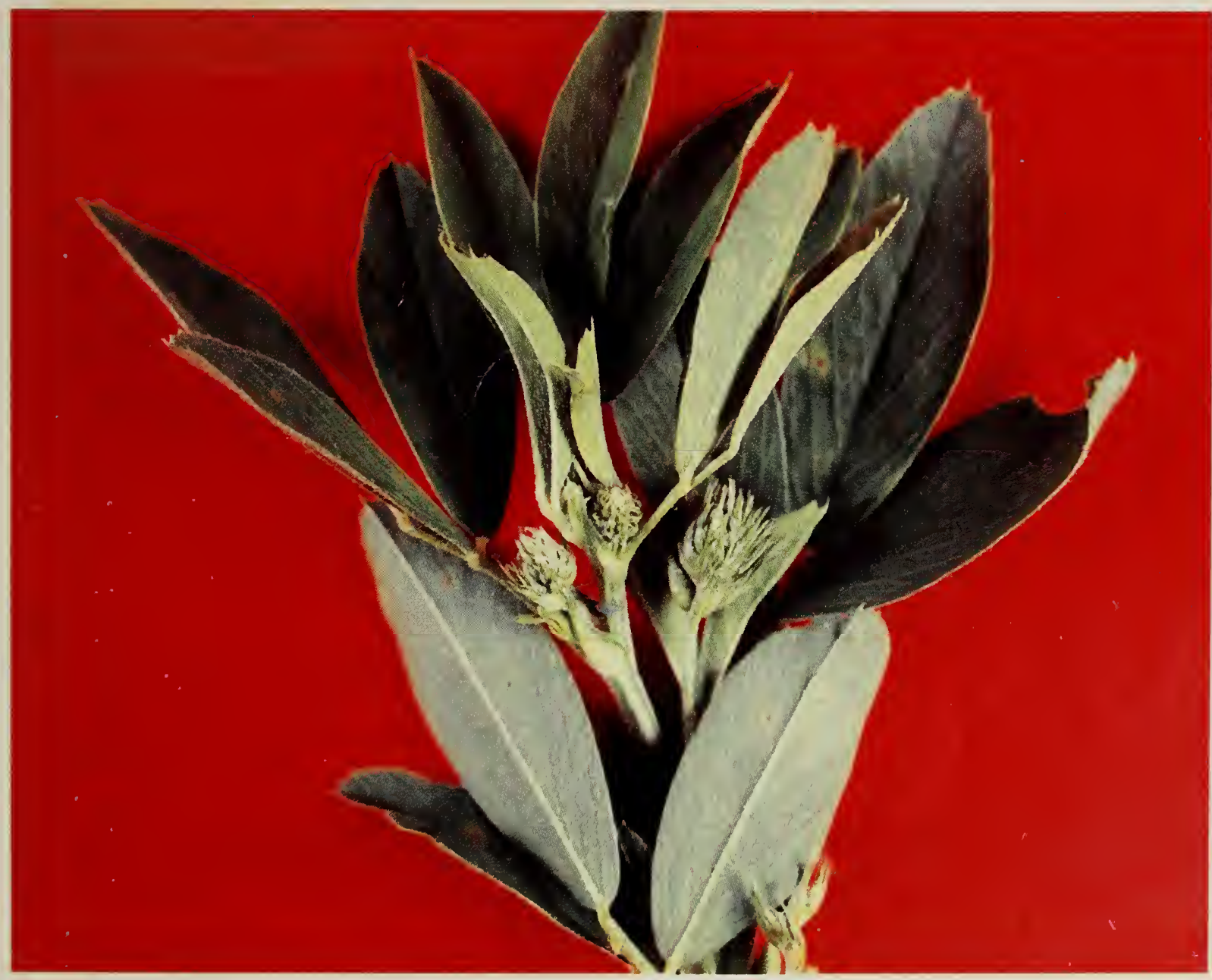


Digitized by the Internet Archive in 2012 with funding from

Agriculture and Agri-Food Canada - Agriculture et Agroalimentaire Canada 


\section{Alfalfa production and management in Atlantic Canada}

M. Suzuki, R. Andrew, J.A. Ivany, J. Kimpinski, H.T. Kunelius, R.A. Martin, P. Narasimhalu, and L.S. Thompson

Research Station

Charlottetown, P.E.I.

Recommendations for pesticide use in this publication are intended as guidelines only. Any application of a pesticide must be in accordance with directions printed on the product label of that pesticide as prescribed under the Pest Control Products Act. Always read the label. A pesticide should also be recommended by provincial authorities. Because recommendations for use may vary from province to province, your provincial agricultural representative should be consulted for specific advice.

\section{Cover illustration}

Alfalfa at late bud stage ready to be harvested

Agriculture Canada Publication 1833/E available from

Communications Branch, Agriculture Canada

Ottawa K1A 0C7

${ }^{\oplus}$ Minister of Supply and Services Canada 1989

Cat. No. A53-1833/1989E ISBN 0-662-16835-6

Printed $1989 \quad 6 \mathrm{M}-05: 89$

Également disponible en français sous le titre Production et exploitation de la luzerne dans les provinces de l'Atlantique 



\section{CONTENTS}

Why grow alfalfa 7

Field selection 8

Climatic requirements 8

Soil requirements 9

Cultivar selection 10

Establishment 11

Seedbed preparation 11

Soil testing 11

Liming 12

Seeding-year fertilization 12

Weed control 15

Inoculation and seeding 17

Reseeding 18

Managing established stands 19

Cutting 19

Post-seeding fertilization 21

Harvesting and storage 22

Diseases 25

Harmful insects and nematodes 28

Winter survival 32

Feeding to animals 34

Production costs 34

Bibliography 37 



\section{WHY GROW ALFALFA}

Alfalfa production in Atlantic Canada was estimated at about 5000 ha in 1978 and 25000 ha in 1987, and further increases in production are expected in the future.

Some of the advantages of alfalfa production are:

- Alfalfa is a high-yielding perennial legume that produces two crops or more annually up to 5 years and is particularly suited for a long-term program.

- Alfalfa produces high-quality forage with high concentrations of protein and calcium, and some vitamins.

- Alfalfa makes excellent hay and silage suitable for feeding dairy and beef cattle.

- Alfalfa makes high-quality hay and dehydrated products of high market value.

- Alfalfa requires little nitrogen fertilizer because it fixes nitrogen from the air.

- Alfalfa develops a deep root system, improves subsoil structure, and is tolerant to drought.

- Alfalfa provides nitrogen both to companion and succeeding crops. 


\section{FIELD SELECTION}

Selection of a suitable site is a prerequisite to the successful production of alfalfa, which performs well only under specific climatic and soil conditions.

\section{CLIMATIC REQUIREMENTS}

- Alfalfa requires the accumulation of sufficient heat units, being equivalent to 350 growing degree days (GDD), before the first cut as well as between harvests. On the map of optimum cutting date (Fig. 1), most areas of Zones 1, 2, and 3 meet this requirement; Zone 4 is difficult for alfalfa production, and Zone 5 should be avoided.

- Intensive management with a three-cut system requires extra GDD and should be practiced only in Zones 1 and 2 .

- Avoid overly exposed areas and select fields in which snow cover is likely to stay on the ground throughout the winter.

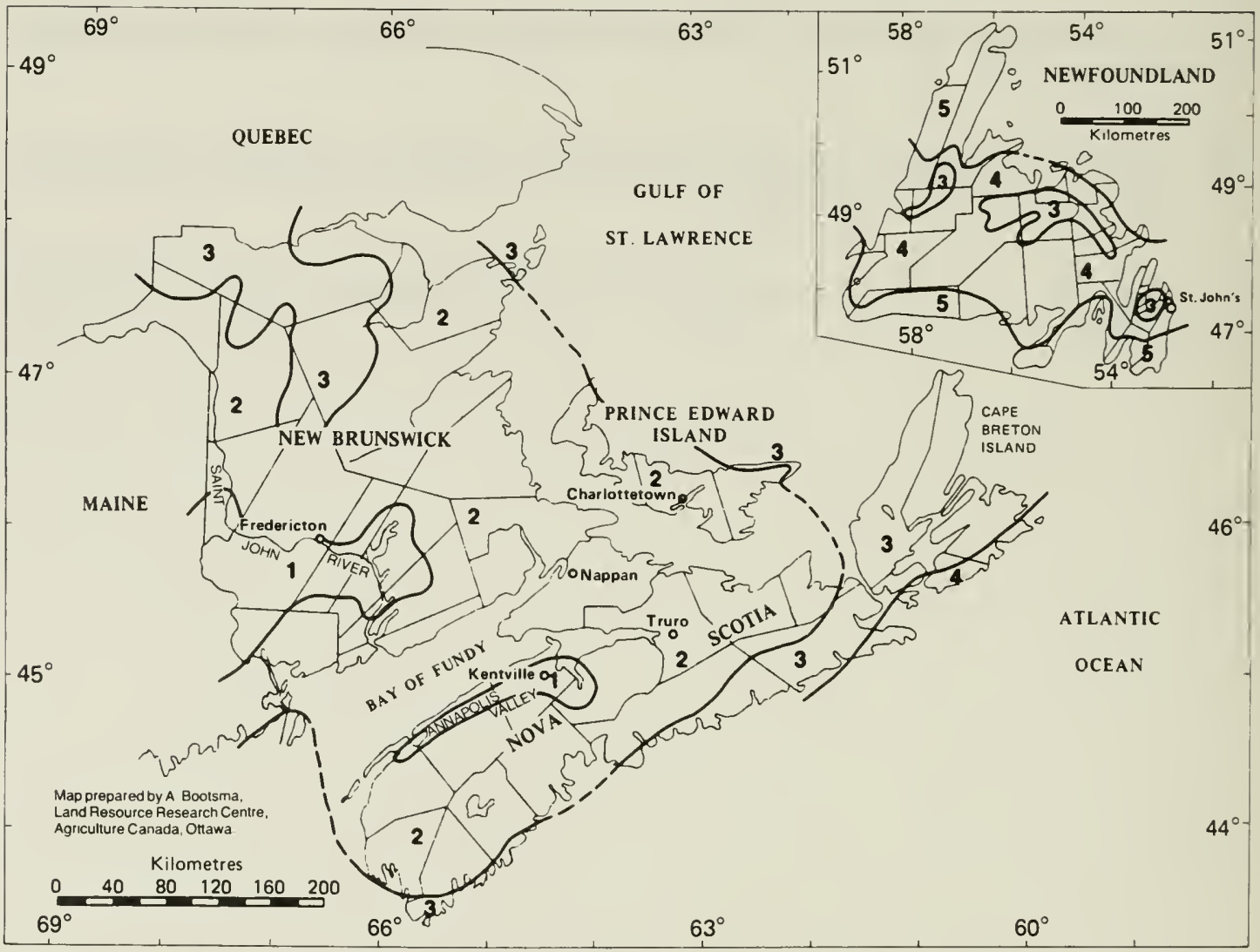

Figure 1 Zones for optimum date of first cut of alfalfa. Optimum dates for first cut are: 6-18 June for Zone 1, 14-26 June for Zone 2, 22 June-4 July for Zone 3, 30 June-12 July for Zone 4, and 8 July or later for Zone 5. 


\section{SOIL REQUIREMENTS}

- In the Maritime Provinces, select a field from the areas as indicated in the soil capability map (Fig. 2).

- In Newfoundland, select a field with sandy loam to loam textured mineral soils, particularly those suitable for growing cabbage, turnip, and other vegetables. Avoid peat soils.

- Select a field with good drainage. Alfalfa is adapted to soils that are naturally well drained or tile drained. Alfalfa develops root systems to a depth of $1 \mathrm{~m}$ in most areas of the region (Fig. 3). Consequently, a water table of $1 \mathrm{~m}$ or higher may adversely affect alfalfa. A water table higher than $50 \mathrm{~cm}$ for 2 weeks or longer may cause serious damage to alfalfa.

- Avoid fields where heavy, wet soil is susceptible to frost heave.

- Examine field conditions in early spring when snow starts melting and select a field from which melted snow will drain quickly without causing waterlogging or ice sheet cover.

- Select a field with $18 \mathrm{~cm}$ or deeper topsoil and avoid one with extremely compacted and acidic subsoil.

- Select a field with low weed populations, and without residues of triazine herbicides in soil.

- Do not seed alfalfa immediately after alfalfa.

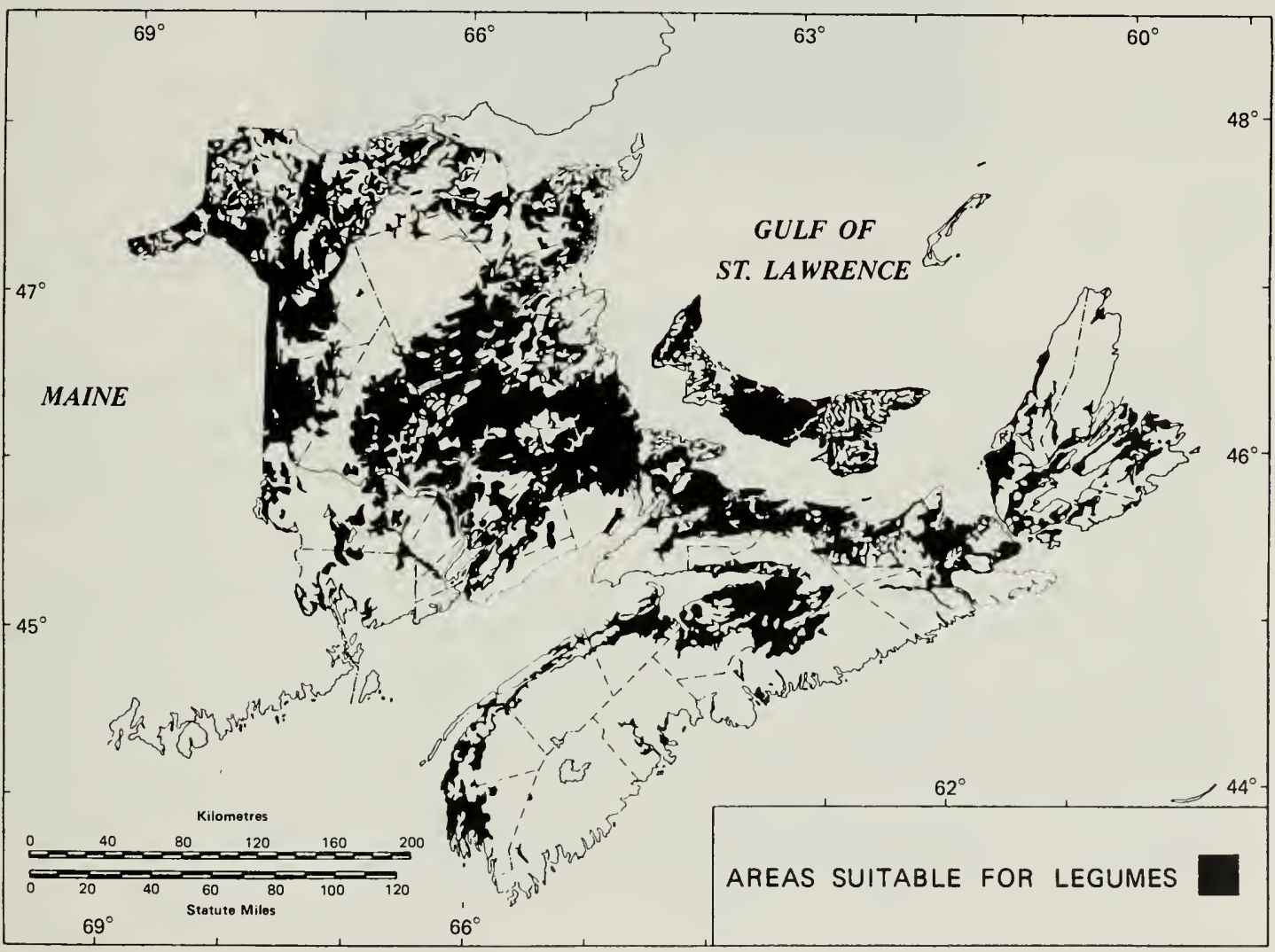

Figure 2 Soil capability map for forage legume production in the Maritime Provinces (from MacMillan and Suzuki, Canadex 524-125). The dark-colored areas have soils capable of producing alfalfa. 


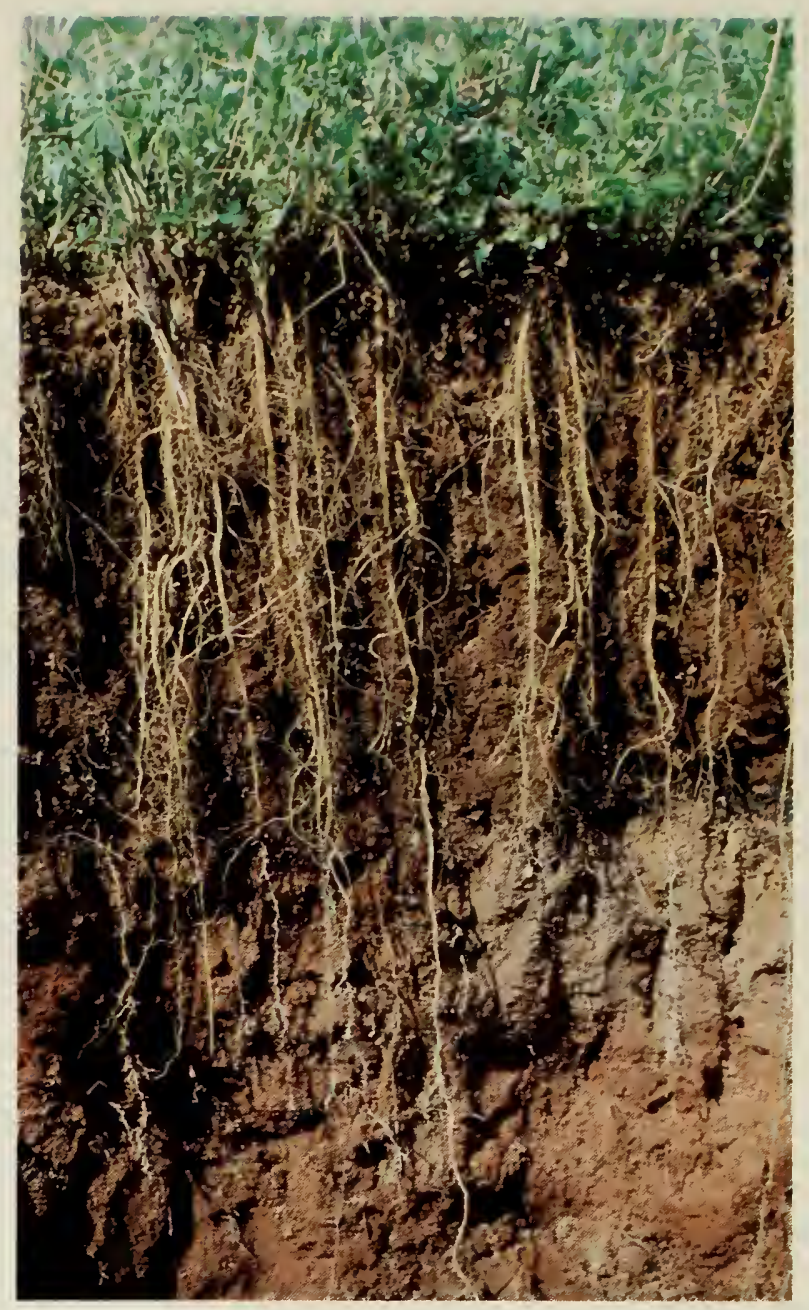

Figure 3 Root system of 3-month-old alfalfa.

\section{CULTIVAR SELECTION}

Select cultivars that have been proven to perform well in the region. Every year the Atlantic Advisory Committee on Forage Crops recommends cultivars after trials in the region for yield, winterhardiness, disease, insect resistance, and other agronomic characters (Field Crop Guide to Variety and Pesticide Selection. Publication 100A).

Two types of alfalfa, Flemish and Standard, are available, with little difference in yield or hardiness between the two. Flemish-type cultivars, such as Saranac and Apica, mature earlier, recover more rapidly after cutting, and become dormant later in the fall than Standard-type cultivars, such as Iroquois and Algonquin. Either type is suitable for a two-cut system. For a three-cut or intensive management system, choose a Flemish-type cultivar; if a field is imperfectly drained, select a Standard-type cultivar.

Use cultivars with resistance to a wide range of diseases. All currently recommended cultivars are more or less resistant to bacterial wilt disease. However, none is resistant to verticillium wilt disease, which is one of the most destructive diseases of alfalfa. As they become available, select cultivars resistant to verticillium wilt; availability of such cultivars in Atlantic Canada is as yet limited. 


\section{ESTABLISHMENT}

\section{SEEDBED PREPARATION}

\section{Cropped Land}

For seeding alfalfa after annual or biennial crops, apply and incorporate necessary amounts of lime into the soil during the previous fall, depending on soil test results. For a potato field, use extra lime as needed. Apply manure at the same time. Prepare a weed-free field (see "Weed control"). Note that no herbicide treatment is necessary for a clean field. Avoid overworking the soil as it may increase soil erosion. Plow in the fall as required; a satisfactory seedbed can be prepared by discing and harrowing in the spring.

\section{Sod area}

To reduce weed populations and weed competition, it is advisable to grow annual forage crops, cereals, or horticultural crops before establishing alfalfa. If alfalfa is to be seeded on a field in sod, minimize weed infestation by applying a herbicide such as glyphosate (Roundup) and by fall plowing. Reduce perennial weeds by thorough cultivation. Apply lime and manure and cultivate in the fall. Cultivate again, and disc and harrow before seeding in the spring. In fields of very sandy and light soil with a potential for erosion avoid fall plowing. (For direct seeding in sod, see "Reseeding".)

\section{Newly cleared land}

Seeding alfalfa in newly cleared land is not generally recommended, because the virgin soil is too acidic for alfalfa and it is difficult to prepare a satisfactory seedbed.

\section{SOIL TESTING}

Soil testing should serve as the main guide to determine lime and fertilizer requirements for alfalfa. Soil tests indicate soil $\mathrm{pH}$, organic matter, and availabilities of phosphorus $(\mathrm{P})$, potassium $(\mathrm{K})$, calcium $(\mathrm{Ca})$, and magnesium $(\mathrm{Mg})$ in the soil. Requirements for nitrogen $(\mathrm{N})$, boron $(\mathrm{B})$, sulfur $(\mathrm{S})$, and some other nutrients are better determined by plant analysis and field diagnosis. Soil samples should be tested in the previous summer or fall before seeding. 


\section{LIMING}

Alfalfa performs well within a soil $\mathrm{pH}$ range of 6.5-7.5; the optimum is considered to be 6.8. However, this high level is not always easy to achieve in the region, and excess liming may restrict availability of some micronutrients. Therefore, liming soils only to pH 6.5 is recommended for Atlantic Canada.

At least 6 months before seeding, apply lime evenly throughout the field by using a split application-one half of the rate in one direction and the other half in the crosswise direction. Incorporate lime into the soil and mix well to $15 \mathrm{~cm}$ or deeper.

Soil testing will indicate whether dolomitic or calcitic limestone is the best to use for the field. Finely ground dolomitic limestone is normally the most suitable material, as it contains $\mathrm{Ca}$ and $\mathrm{Mg}$, both of which are essential nutrients of alfalfa. Use calcitic limestone if the soil $\mathrm{Mg}$ level is adequate and $\mathrm{Ca}$ only is required.

\section{SEEDING-YEAR FERTILIZATION}

General recommendations are available in the Field Crop Guide for the Atlantic Provinces, but this is only a general guide. Kinds and rates of fertilizers should be determined by the soil test.

\section{Nitrogen}

Alfalfa, when properly inoculated, requires little or no $\mathrm{N}$ fertilizer, because the $\mathrm{N}$-fixing bacteria in nodules supplies $\mathrm{N}$. However, until enough nodules are developed, a small amount of $\mathrm{N}$ fertilizer is needed. The optimum rate of $\mathrm{N}$ fertilizer depends on the type of soil, organic matter content, preceding crops, and manure application. Avoid excess application of $\mathrm{N}$ fertilizer, as it encourages growth of grass and weeds and retards development of nodules.

Nitrogen-deficiency symptoms Dwarfed, spindly growth with general yellowing.

\section{Phosphorus}

$P$ is particularly important in developing a good root system. Placing P slightly below the seed as applied by a drill seeder is more effective than broadcasting.

Phosphorus-deficiency symptoms Small and dark green leaves; stunted, stiff, and erect growth; folded leaflets with purplish undersides; yellow and dying older leaves. 


\section{Potassium}

Insufficient application of $\mathrm{K}$ is often a limiting factor in production of alfalfa in Atlantic Canada. Apply the required amount of $\mathrm{K}$ according to the soil test.

Potassium-deficiency symptoms Small white spots at leaflet margins; yellow older leaves with brown necrosis along margins; gray spots and pinkish cinnamon color of older leaves (Fig. 4).

\section{Calcium and magnesium}

Dolomitic limestone is a good source of $\mathrm{Ca}$ and $\mathrm{Mg}$. If soil is limed with dolomitic limestone to raise $\mathrm{pH}$ to 6.5 , there will be no need of applying extra $\mathrm{Ca}$ and $\mathrm{Mg}$ fertilizers.

Calcium-deficiency symptoms Sudden collapse of the petioles of the youngest fully developed leaves.

Magnesium-deficiency symptoms Interveinal chlorosis of leaflets progresses from older to younger leaves.

\section{Boron}

Soils in Atlantic Canada are often low in available B. In the seeding year, the spring application of a fertilizer mixture before seeding should be supplemented with $0.2-0.4 \%$ B to provide $1.0 \mathrm{~kg} / \mathrm{ha}$ of boron.

Boron-deficiency symptoms Reddish or purplish leaf discoloration; internode shortening (Fig. 5).

\section{Other nutrients}

Alfalfa requires trace amounts of molybdenum (Mo), copper $(\mathrm{Cu})$, iron $(\mathrm{Fe})$, zinc $(\mathrm{Zn})$, and manganese $(\mathrm{Mn})$, which are essential micronutrients. However, application of these elements is not required unless deficiency symptoms appear on alfalfa.

\section{Manure}

Barnyard manure, besides providing $\mathrm{N}, \mathrm{P}, \mathrm{K}$, and some micronutrients, improves the physical condition of the soil. Application of manure will be particularly effective for soils low in organic matter. Apply barnyard manure the year prior to seeding to allow for decomposition of the manure and the germination of weed seeds. 


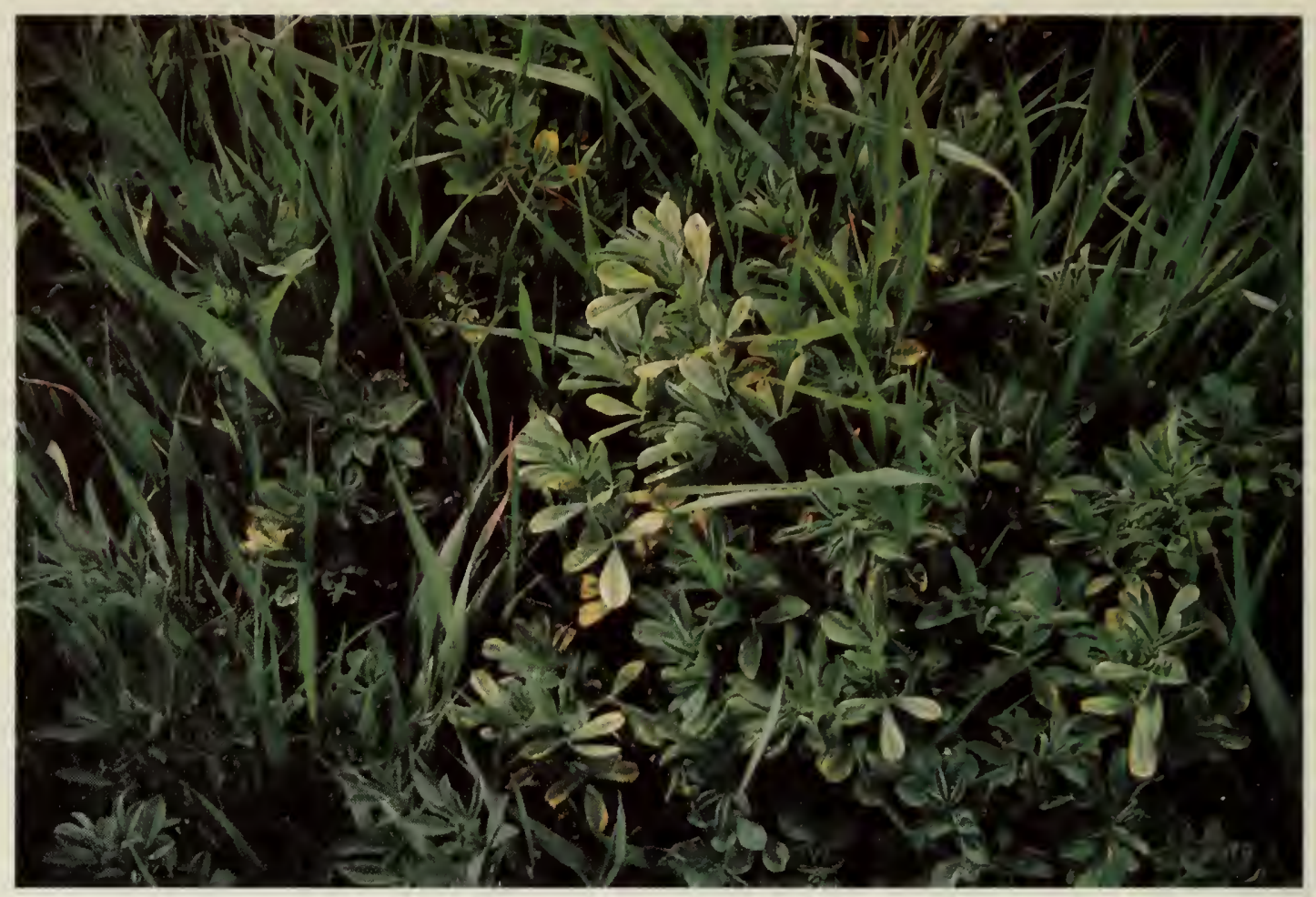

Figure 4 K-deficient alfalfa.

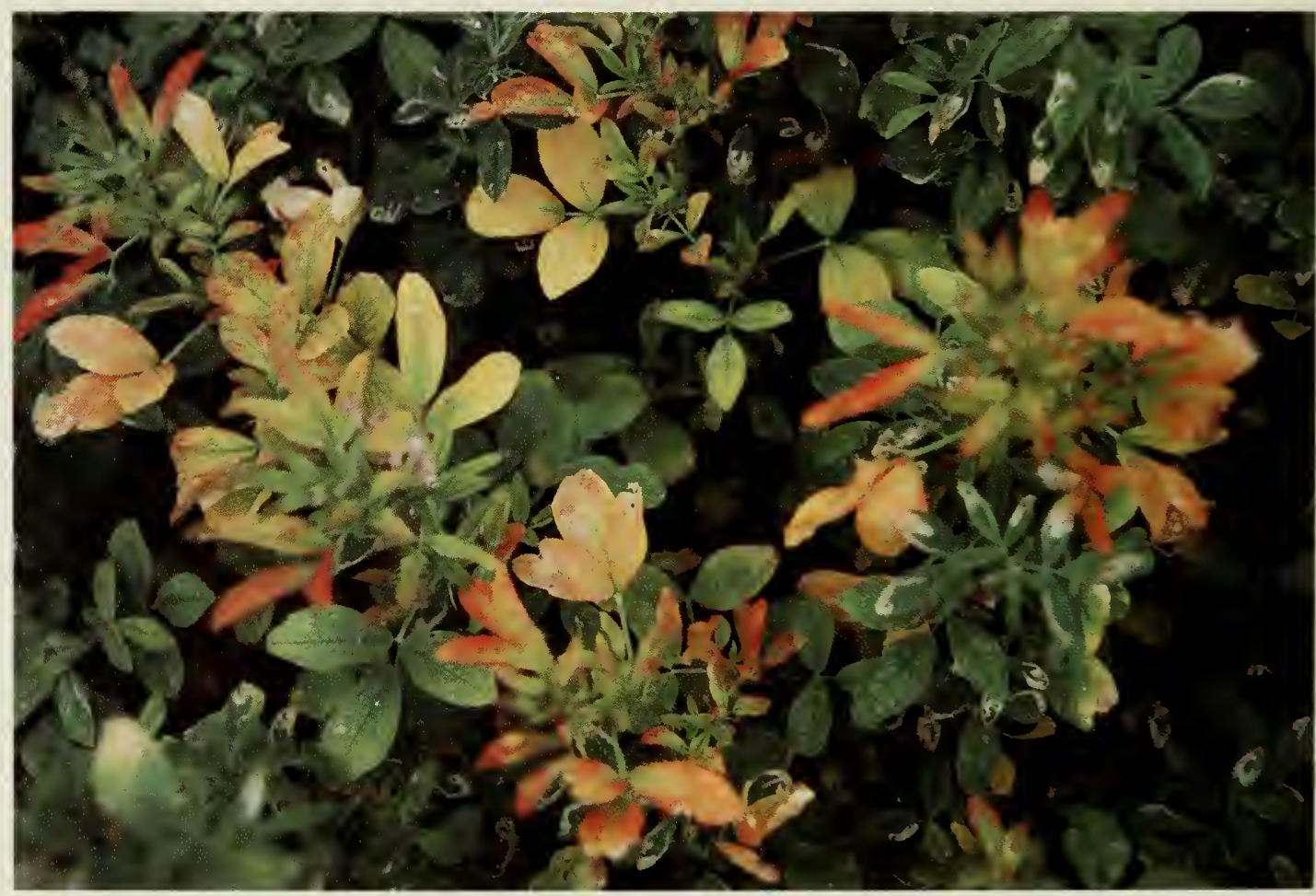

Figure 5 B-deficient alfalfa. 


\section{WEED CONTROL}

In the seeding year, competing weeds may prevent the establishment of a good stand. Competition from weeds can reduce the number of plants, retard the growth, and weaken the plants and may result in greater risk of winterkill. Always use weed-free, certified seed to get the crop off to a good start and to prevent introducing new weed species to the field. Select fields for alfalfa that are as free of weeds as possible so as to get a vigorous alfalfa stand established. Establish alfalfa following a crop that has had good weed control such as annual forage crops, cereals, or horticultural crops. Make sure, however, that no residues of persistent herbicides remain in the soil, such as triazines to which alfalfa is susceptible. Triazine residues are more detrimental to alfalfa at higher soil $\mathrm{pH}$. Avoid, whenever possible, establishing alfalfa in old pasture or neglected fields as weed growth will be considerable once the field is "broken."

\section{Mechanical Weed Control}

\section{Pre-planting control}

Choose fields for alfalfa in advance and plow them in the year before seeding, if possible. This schedule allows for two or three spring cultivations to destroy any annual weed seedlings that germinate. Allow 7-10 days between cultivations to stimulate more weeds to germinate. By reducing the weed population the newly seeded alfalfa gets off to a better start, free from weed competition.

\section{Post-planting control}

After emergence of alfalfa, use "clipping" as an effective way to control upright-growing, annual weeds. The time of clipping is quite important and on this timing depends the development of both alfalfa and weeds. Clipping is done while the weeds are growing taller than the alfalfa and must be completed before the weeds go to seed. Mow so that no swath is produced as alfalfa seedlings will be killed by a swath that is too thick. Mow at a height of about $8-10 \mathrm{~cm}$ so that most of the leaves removed are from the weeds. Mowing too high encourages weeds to branch out and grow back causing severe competition with alfalfa seedlings. Alfalfa planted in mid May can usually be clipped in mid to late June if weeds are affecting alfalfa growth. If weeds are not a serious threat, clipping can be delayed to use alfalfa and weeds harvested for green chop, hay, or silage. 


\section{Chemical weed control}

Several herbicides are available to control weeds in direct-seeded, pure alfalfa. These herbicides have limitations as to the weeds that they control so know the weed species that are present in the fields before selecting a herbicide to use. It is better to use a herbicide along with clipping to control weeds. For the most up to date herbicide recommendations, consult crop-production guides and staff at the local District Office of the provincial Department of Agriculture.

Herbicides recommended for direct-seeded alfalfa at the time of writing this report are described below.

\section{Preplant incorporated herbicides}

EPTC (Eptam)* This herbicide controls germination of many annual grasses and broadleaf weeds but it is ineffective on weeds in the mustard family. Apply it to a dry soil surface and incorporate it into the soil immediately.

Trifluralin (Treflan, Rival) These two products contain the same active herbicide and give good control of germination of annual grasses, lamb's-quarters, and pigweed but do not control weeds in the mustard family. Apply either to the soil surface and incorporate it before seeding the alfalfa.

\section{Postemergence herbicides}

2,4-DB (Embutox) This herbicide applied postemergence will control many emerged broadleaf weeds, but time of application is critical. Only apply it when the alfalfa is in the 1-3 trifoliate leaf stage. Later applications will result in severe crop injury. Even when applied at the correct stage, crop growth can be suppressed for 2-3 weeks. Note that under drought, high temperature, or stress conditions, Embutox can severely injure alfalfa.

2,4-DB + MCPA (Embutox + MCPA) Use of this mixture will result in improved control of mustards. Note that overapplication of MCPA can severely damage alfalfa.

* Common name (Example of trade name) 


\section{INOCULATION AND SEEDING}

\section{Inoculation}

Use certified seed of a recommended cultivar. It is important to inoculate alfalfa seeds with active Rhizobium bacteria. Various strains of Rhizobium bacteria are available, but "Balsac inoculant" is recommended for the region. Keep inoculum in airtight containers in a refrigerator until used to inoculate seeds immediately before seeding. If necessary, store inoculated seed in a cool and dark place, but for 1-2 days only. After three days of storage, reinoculate seed with fresh inoculant.

\section{Seeding}

\section{Seeding time}

Seed as soon as the land can be worked in the spring. The optimum seeding date varies from mid May to early June, depending on location, soil moisture, and temperature. Seeding in summer or fall is not recommended.

\section{Seeding rate}

Seed alfalfa in a pure stand at $12-16 \mathrm{~kg} / \mathrm{ha}$. If the germination rate is low, increase the seeding rate according to the germination test result. Alfalfa $(12 \mathrm{~kg} / \mathrm{ha})$ may be seeded in a mixture with timothy (4-6 kg/ha), bromegrass $(6-8 \mathrm{~kg} / \mathrm{ha})$, or orchardgrass (4-6 kg/ha).

\section{Seeding depth}

The optimum seeding depth is $1.0 \mathrm{~cm}$. Do not seed deeper than $2.0 \mathrm{~cm}$. To ensure a shallow seeding, prepare and sow on a firm seedbed.

\section{Direct-vs. under-seeding}

Direct-seeding, which is generally recommended for alfalfa production, results in better establishment. Alfalfa without a cover crop is easier to manage than under-seeded alfalfa. If seeded with a cereal companion crop, reduce seeding rate of the cereal crop and harvest the cereal before it reaches the late-dough stage to reduce competition. 
The cultipacker (Brillion-type) seeder ensures shallow seeding and even distribution of seeds. The soil is firmed into shallow corrugations by the first roller. Immediately after placing seeds, the second roller firms the seedbed.

Grain drills have been used successfully for band seeding of alfalfa. This method of seeding on a band of fertilizer results in a more efficient use of fertilizer. Add presswheels to the seeder to firm the seedbed and to ensure good contact of seeds with soil.

\section{RESEEDING}

Reseeding of alfalfa may become necessary to maintain adequate density of alfalfa. But this technique goes against the basic rule of "Do not seed alfalfa immediately after alfalfa" and should be practiced with caution. Do not reseed fields where the previous stand of alfalfa was infected with soil-borne pathogens, such as root and crown rots, sclerotinia crown and stem rot, verticillium wilt, or root lesion nematodes. Alfalfa should not be sod-seeded in fields with heavy quack grass (couch grass) and other weed infestation.

Sod-seeding is a fast, minimum-tillage technique for renovating rundown alfalfa fields. Sod-seeding of alfalfa works best in fields with open sward. Close grazing before or immediately after sod-seeding reduces plant competition and aids in seedling establishment. In preparation for spring seeding, spray glyphosate (Roundup) the previous fall for vegetation control. Apply lime and fertilizer as specified by soil testing for alfalfa. Do not apply nitrogen fertilizer as it increases competition from grasses. In the spring, it may be necessary to cultivate lightly or to spray with suitable herbicides (or both) to reduce competition. Spraying paraquat (Gramoxone) or glyphosate (Roundup) at least 1 week before seeding improves seedling establishment.

Pasture renovators, which are designed for sod-seeding, require little or no seed bed preparation before seeding and result in good establishment. A grain drill will do a satisfactory job but some seed bed cultivation is usually required. Adjust the disc tension to obtain proper seeding depth of $1-2 \mathrm{~cm}$. Cultipacker (Brillion-type) and broadcast seeding usually require extensive cultivation if the sod covers the ground, as the seed has to be in contact with the soil for satisfactory germination.

Earlier seeding in the spring results in better establishment of sod-seeded alfalfa; sod-seeding after mid June will be less successful. Recommended seeding rate for alfalfa is $10-15 \mathrm{~kg} / \mathrm{ha}$, and seed should be inoculated before seeding.

To maintain a good stand, allow sod-seeded alfalfa to reach the bud stage before the first cut, which allows it to establish well. 


\section{MANAGING ESTABLISHED STANDS}

\section{CUTTING}

Cutting management of alfalfa is vital to seasonal production, forage quality, winter survival, and longevity of stand. The quality of alfalfa is closely related to the maturity at harvest. As alfalfa matures, fiber content increases, feeding value goes down, and animals eat less.

A two-cut system for alfalfa is common in the region but three cuts may be taken in milder climatic zones, (see Zones 1 and 2 in Fig. 1). In other climatic zones, a longer life-span of alfalfa can be expected under a two-cut system.

Under a two-cut system, take the first cut in June when alfalfa is in the late bud to early flowering stage (Fig. 6). The second cut is usually taken $35-42$ days after the first cut. The third harvest may be taken in October when growth has ceased. Leave a stubble of $10-15 \mathrm{~cm}$ so as not to disturb development of new shoots and to catch and hold snow, which helps to prevent winter injury from wind and ice.

If the third cut is to be taken before the starting date of the fall rest period (Fig. 7), take the first and second cuts earlier than for the two-cut system. If no blooms or buds are visible on top growth, examine to see if enough buds are developing on stem bases and crowns. The new shoots will start growing from these buds; if 10 or more crown buds are visible, the alfalfa is ready to be cut.

No cutting is recommended during the essential fall rest period, during which alfalfa accumulates adequate levels of reserves in roots and crowns for overwintering and for active spring growth. New shoot growth depletes root reserves in about 3 weeks following cutting.

In Atlantic Canada, alfalfa does not perform well as pasture, and it is not recommended for grazing purposes. If alfalfa is to be grazed, special precautions should be taken so that it will not be grazed too closely or too frequently. After grazing, alfalfa pasture needs a sufficient rest period, 350 GDD or more (see "Climatic requirements") in which to recover and build up root reserves. Caution must be exercised when grazing alfalfa as excess intake can cause animals to bloat. 

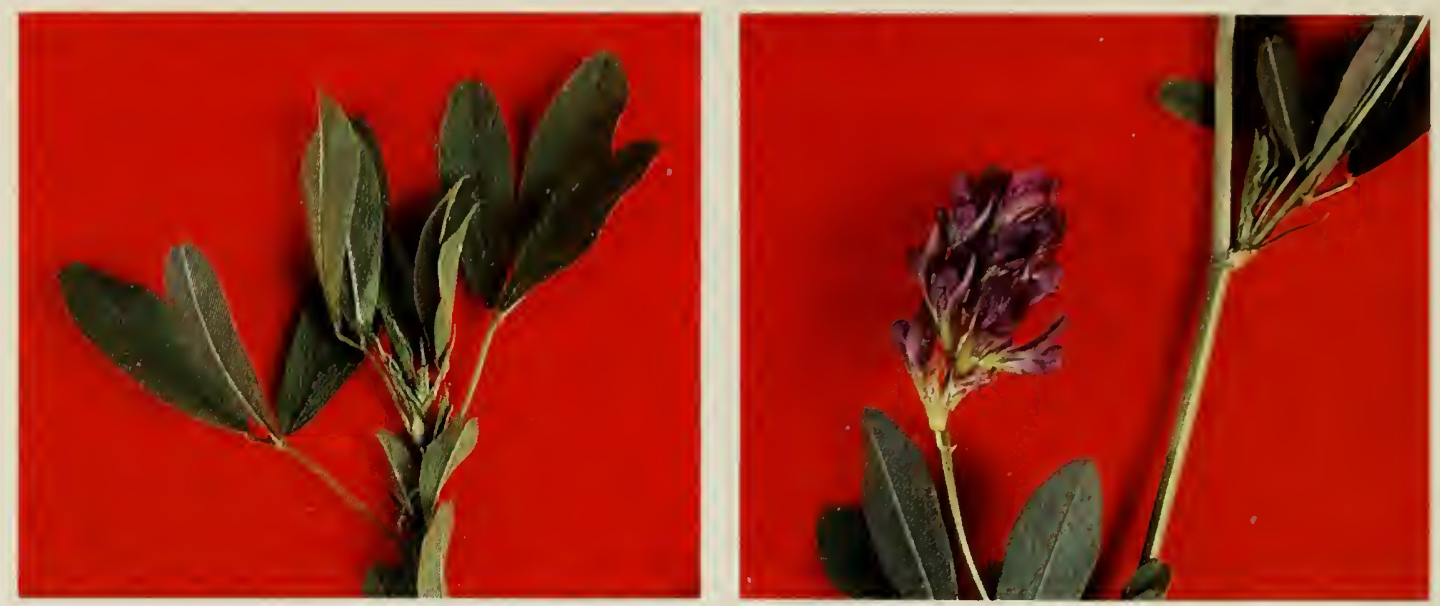

Figure 6 Alfalfa at early bud stage (left), late bud stage (cover), and bloom stage (right).

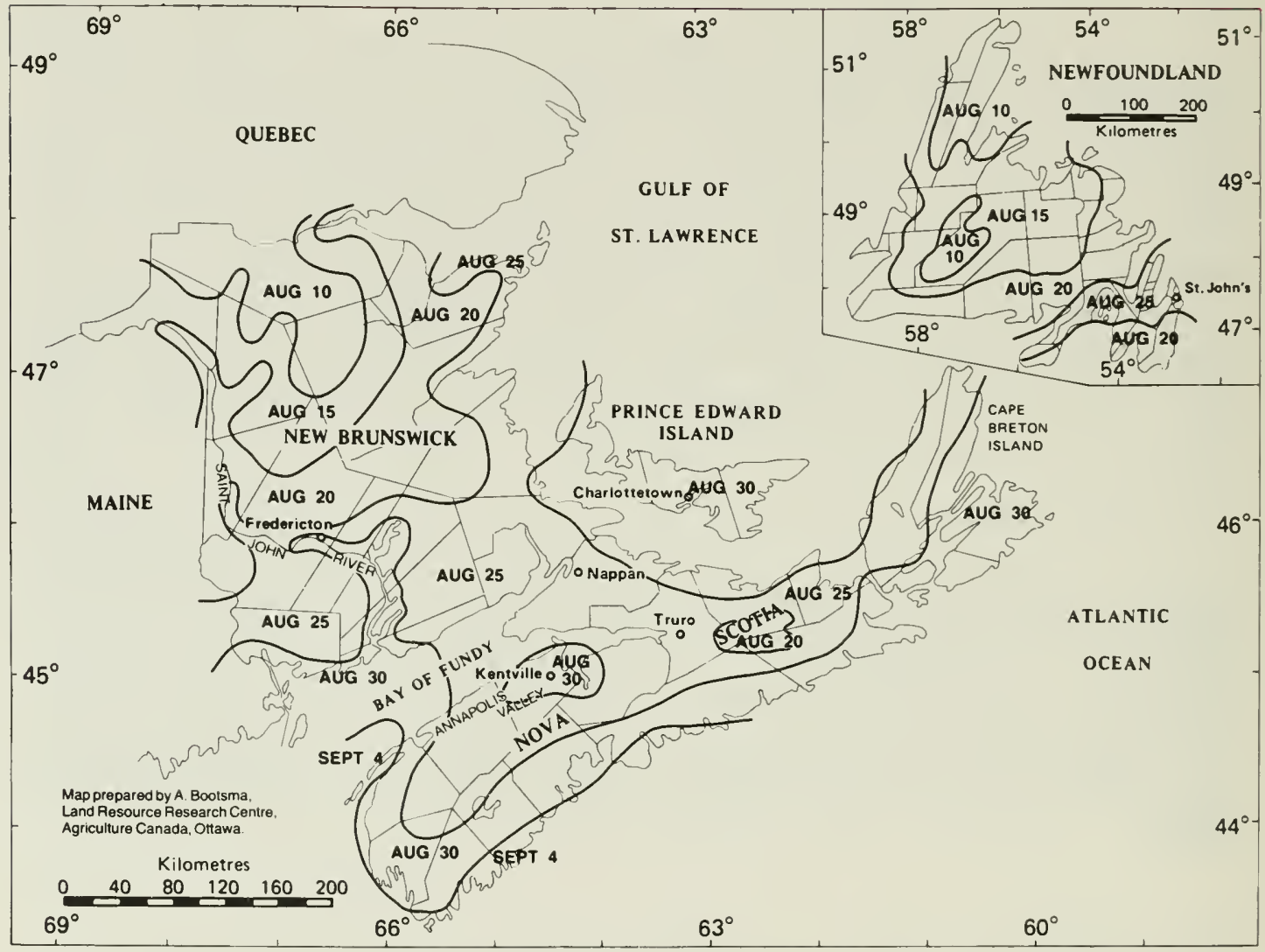

Figure 7 Starting date of fall rest period for alfalfa (do not cut alfalfa for 2 weeks after the starting date). 


\section{POST-SEEDING FERTILIZATION}

Alfalfa is unable to maintain a productive and thick stand unless it receives adequate lime and fertilizer. Soil tests should be performed once every 2 or 3 years after establishment. More frequent testing will be necessary, if any nutrient-deficient symptoms appear in the stand.

\section{Nitrogen}

A small amount of nitrogen may be used to stimulate early spring growth. Avoid excess application of $\mathrm{N}$ that will result in weakening of alfalfa stands by providing competition from grasses and weeds.

\section{Potassium}

Alfalfa takes up a large amount of $\mathrm{K}$ from the soil. Apply relatively high rates of $\mathrm{K}$ in the spring and also after first or second cuts, or both. The time of application is not essential, provided sufficient quantities are applied to support the productive stand.

\section{Phosphorus}

$P$ will be required in early spring. For well-established alfalfa stands, phosphorus will not be needed after each cut, except for soils low in $\mathrm{P}$.

\section{Calcium and magnesium}

$\mathrm{Ca}$ is essential for maintenance of healthy stands of alfalfa. Lime every 3 years to maintain soil $\mathrm{pH}$ at around 6.5 , which will normally ensure a sufficient supply of $\mathrm{Ca}$ and $\mathrm{Mg}$.

Boron

B should be applied at 3- or 4-year intervals. In light-textured soils, however, applications every second year are advisable.

\section{Sulfur}

Although the level of available $\mathrm{S}$ in most soils in Atlantic Canada only marginally meets the needs of alfalfa, there is usually no need to apply S. Apply S only when alfalfa shows deficiency symptoms, such as yellowing of the entire plant in summer and reddening of stems. 


\section{Manure}

Application of barnyard manure at a high rate may smother and damage established stands. Manure can be applied safely either immediately after the stands are cut or in the fall. Late fall application after alfalfa becomes dormant is safer than application during the growing season. Apply only well-rotted manure low in $\mathrm{N}$ and with limited weed seed content.

The importance of soil testing and applying sufficient lime and fertilizer, particularly potassium, cannot be overemphasized for maintenance of healthy and thick stands of alfalfa.

\section{HARVESTING AND STORAGE}

\section{Harvesting}

Yield and quality of alfalfa and the potential intake by animals are affected by the crop's maturity at harvest (Table 1).

Alfalfa should be harvested between the bud and the $10 \%$ bloom stage (see Fig. 6) to obtain good yields of crude protein (1.2 t/ha) and digestible dry matter $(4.0 \mathrm{t} / \mathrm{ha})$. Properly harvested alfalfa is an excellent source of $\mathrm{Ca}$ and carotene, the latter being used by animals as a source of vitamin $A$.

Harvest operations and weather conditions at harvest can affect the extent to which nutrients present in the standing crop are retained in stored hay or silage. In Atlantic Canada, the driest season is between early July and mid August. During the rest of the cropping season, a good field-drying day is often followed by one or more days of unfavorable weather, making it essential that harvest operations be completed within a limited time. It is advisable to use a rotary or disc-type mower-conditioner, which cuts fast and reduces the time needed for field-drying.

Table 1 Stage of maturity, yield, composition, and intake potential of alfalfa

\begin{tabular}{|c|c|c|c|c|c|}
\hline \multirow{2}{*}{$\begin{array}{c}\text { Stage } \\
\text { of } \\
\text { maturity }\end{array}$} & \multirow{2}{*}{$\begin{array}{c}\text { Dry } \\
\text { matter } \\
\text { yield* } \\
\text { (kg/ha) }\end{array}$} & \multicolumn{3}{|c|}{ Composition (\% of dry matter) } & \multirow{2}{*}{$\begin{array}{c}\text { Intake } \\
\text { potential } \\
\text { (kg dry matter } / \\
100 \mathrm{~kg} \text { live wt) }\end{array}$} \\
\hline & & $\begin{array}{l}\text { Crude } \\
\text { protein }\end{array}$ & $\begin{array}{c}\text { Fiber } \\
(=\mathrm{NDF})\end{array}$ & $\begin{array}{c}\text { Digestible } \\
\text { matter }\end{array}$ & \\
\hline Bud & $\begin{array}{c}2900 \\
(5200)\end{array}$ & 18.0 & 40 & 60.0 & $2.5-3.0$ \\
\hline $10 \%$ bloom & $\begin{array}{c}4200 \\
(8500)\end{array}$ & 15.0 & $40-45$ & 58.0 & $2.2-2.5$ \\
\hline $50 \%$ bloom & $\begin{array}{c}4300 \\
(7100)\end{array}$ & 12.0 & $46-51$ & 52.0 & $1.2-1.5$ \\
\hline
\end{tabular}

* Yield of first cut in June followed (in brackets) by total annual yield with second cut obtained between early and mid August. 


\section{Conditioning}

Roller-type conditioners are well suited for crushing the stems, which allows for quick loss of contained water. Adjust the roller tension so that the stems are slightly crushed at $10-$ to $15-\mathrm{cm}$ intervals. Such conditioning neither damages the leaves nor detaches them from the stems. Stem conditioning helps in forming a loose swath, which allows a free flow of air and faster drying of the stems. Conditioned forage dries more uniformly than improperly conditioned or unconditioned forage; stem-drying rate approaches that of leaves.

Flail-type conditioners, especially those fitted with metal instead of plastic fingers, are better suited for grasses than for alfalfa.

A recently developed technique of using both mechanical and chemical conditioning could shorten the field-drying time by a day. For further information concerning chemical conditioning, contact your provincial Department of Agriculture representative.

\section{Drying}

Field drying can be hastened by swath manipulation. By cutting the crop between 8 and $10 \mathrm{~cm}$ in height, the underlying stubble is of sufficient height to enable the swath to dry quickly, uniformly, and cleanly. The stubble ventilates the swath from the bottom, prevents it from getting wet by soil moisture, and also minimizes its contamination from the soil. Proper tedding of the swath hastens its drying. Excessive tedding or raking of swaths, however, increases the chance of soil contamination and leaf losses. Raking swaths of alfalfa with less than $40 \%$ moisture results in a considerable leaf loss.

Alfalfa can be harvested as high-moisture hay (25-30\% moisture) in the form of conventional, rectangular bales. The high-moisture hay has the advantages of reducing field-curing time and leaf losses but requires a barn dryer, or an application of a hay preservative, or both. Hay harvest can be speeded up by using round or large rectangular bales. The optimum moisture content of a large bale is $30-35 \%$ at the time of being picked up by a large baler. Treat large, high-moisture bales with a hay preservative and store them under cover to minimize dry matter losses during storage.

Forced-air drying of moderately moist bales in the barn has distinct advantages over field curing. Dry hay can be stored without any further treatment, if bales are made from windrows containing less than $20 \%$ moisture. 


\section{Silage making}

Direct-cut or field-dried alfalfa can be ensiled in the presence or absence of additives and stored in vertical or horizontal silos. Silage preparation is less dependent on good weather conditions than is haymaking, but alfalfa that is harvested under unfavorable weather may contain less than the ideal amount of water-soluble carbohydrates (easily fermentable sugars). Cutting the crop on a sunny day and field drying the cut material to $50-60 \%$ moisture content are generally sufficient to increase the water-soluble carbohydrate levels to a sufficiently high level (e.g., $10 \mathrm{~g} / 100 \mathrm{~g}$ dry matter) that is required for rapid production of lactic acid in silage.

Fine chopping $(6-10 \mathrm{~mm})$ at pick-up enables good packing of silage, which eliminates oxygen and improves the chances of rapid acid production. Fine-chopped material releases cell sap containing fermentable sugars that helps in proper fermentation of the silage. Adding up to $100 \mathrm{~kg}$ of crushed grain or $35-40 \mathrm{~kg}$ molasses to 1 tonne of field-dried alfalfa ensiled increases acid production and produces high-quality silage.

Commercially available bacteria inoculants may help to establish "lactic" fermentation, to preserve protein quality, to minimize spoilage, and to produce palatable and digestible silage. However, rapid filling and thorough sealing are often sufficient to make excellent alfalfa silage without the use of an inoculant.

Another method for preserving alfalfa is to add formic acid at about 4-5 L/t of direct-cut alfalfa either at chopping or when loading into the silo. Take extreme care in handling the acid, and hose away acid residues left on the machinery to prevent corrosion.

Loss of dry matter during haymaking runs as high as $25 \%$, whereas during ensiling loss is $5-10 \%$. Loss of nutrients during storage of silage can be as high $25 \%$, whereas hay storage results in $5-10 \%$ losses. Losses from wastage during feeding may be lowered with mechanized feeding of silage, whereas self-feeding either silage or hay usually results in heavy wastage. 


\section{DISEASES}

Alfalfa is subject to several diseases that may limit yield, quality, and longevity. Incidence and severity of diseases can be minimized by adequate management practices.

\section{Root and crown rots}

Root and crown rots of alfalfa are caused by a number of different pathogens, which invade via cracks and wounds in the roots and crowns. Symptoms are varied and are not necessarily specific to a single pathogen. In crowns, early symptoms are brown necrotic areas, whereas in advanced stages the central core is rotted and hollow, and internal root tissue is darkened. Root lesions at advanced stages may girdle the roots resulting in death of the lower portion.

Root and crown rots may cause poor stand development and thinning of established stands. Healthy stands are more able to withstand infection. Plant stress can increase root rot development. Foliar disease, insects, frequent harvests, frost, poor drainage, low fertility, and low soil $\mathrm{pH}$ are some stresses that can enhance root rot development.

Although it may not be possible to prevent root and crown rots totally, good cultural practices such as recommended cutting schedules, adequate fertility, and avoiding excessive mechanical injury help to reduce their severity.

\section{Sclerotinia crown and stem rot}

Sclerotinia infections may occur on crowns and basal stems under mild winter climate with continuous snow cover. Severity varies between seasons, and single plants or entire fields may be infected. Seedlings are most susceptible, although plants of all ages can be infected. This disease is widespread on all forage legumes, but its severity on alfalfa is less than on red clover.

Leaves and stems infected with Sclerotinia trifoliorum become scalded, light brown, and flaccid. White fluffy mycelium may occur over dead plant parts, and hard, black sclerotial bodies up to 8-10 $\mathrm{mm}$ in length may appear on dead plants and on the surrounding soil.

Deep plowing to bury the overwintering sclerotial bodies, maintaining a 3- to 4-year rotation interval between forage legumes, and removal of diseased plants are helpful in controlling this disease.

\section{Spring black stem}

Black stem symptoms appear initially as small brown or black spots. As the disease progresses, spots enlarge and coalesce, and the 
leaves yellow and fall off. Spots may coalesce on stems, girdling the stem, and eventually killing it. Disease development is enhanced by cool, moist weather. The disease organism overwinters on dead leaves and stems and can also be carried on seed. Harvest infected alfalfa stands before the disease becomes too serious.

\section{Common leaf spot}

Common leaf spot (Fig. 8) is a destructive foliar disease that weakens and stunts alfalfa. Premature defoliation reduces vigor, quality, and yield. Small, circular, brown to black spots develop and as the disease progresses leaves turn yellow and drop prematurely. Disease symptoms may appear after the second cut or in the fall. The organism causing the disease overwinters on dead leaves and stems, and it progresses rapidly in cool and wet weather.

When the disease is prevalent, reduce the yield loss by harvesting before defoliation becomes severe. This action also reduces buildup of the organism, which may attack new growth.

\section{Verticillium wilt}

Verticillium wilt (Fig. 9) was identified recently as a problem in a number of fields in Atlantic Canada. It is important, therefore, to be vigilant and to use good management practices to restrict its further spread. The disease pathogen (Verticillium albo-atrum Reinke \& Berth) is spread by direct contact, alfalfa seed, hay and crop debris, footwear, harvest equipment, and some insects.

Symptoms of verticillium wilt start as a general wilting of the upper leaves. The entire plant eventually wilts with leaves yellowing and finally drying up. When new shoots develop, they wilt rapidly and die. Verticillium wilt can reduce dry matter yield and economic life of the stand.

Where the disease is not present, use seed that has been properly treated with appropriate fungicide, such as thiram. The most effective control method is to use cultivars with resistance. None of the currently (1989) recommended cultivars is resistant to verticillium wilt. For information on the availability of resistant cultivars, consult staff at the District Office of the provincial Department of Agriculture.

When the disease is present, cut healthy stands before infested stands; clean and disinfect harvest equipment between fields; plow down infected fields; control susceptible weeds and volunteer plants in plowed fields; and use a rotation system of 3 to 4 years with cereals, corn, or forage grasses before seeding alfalfa again. 


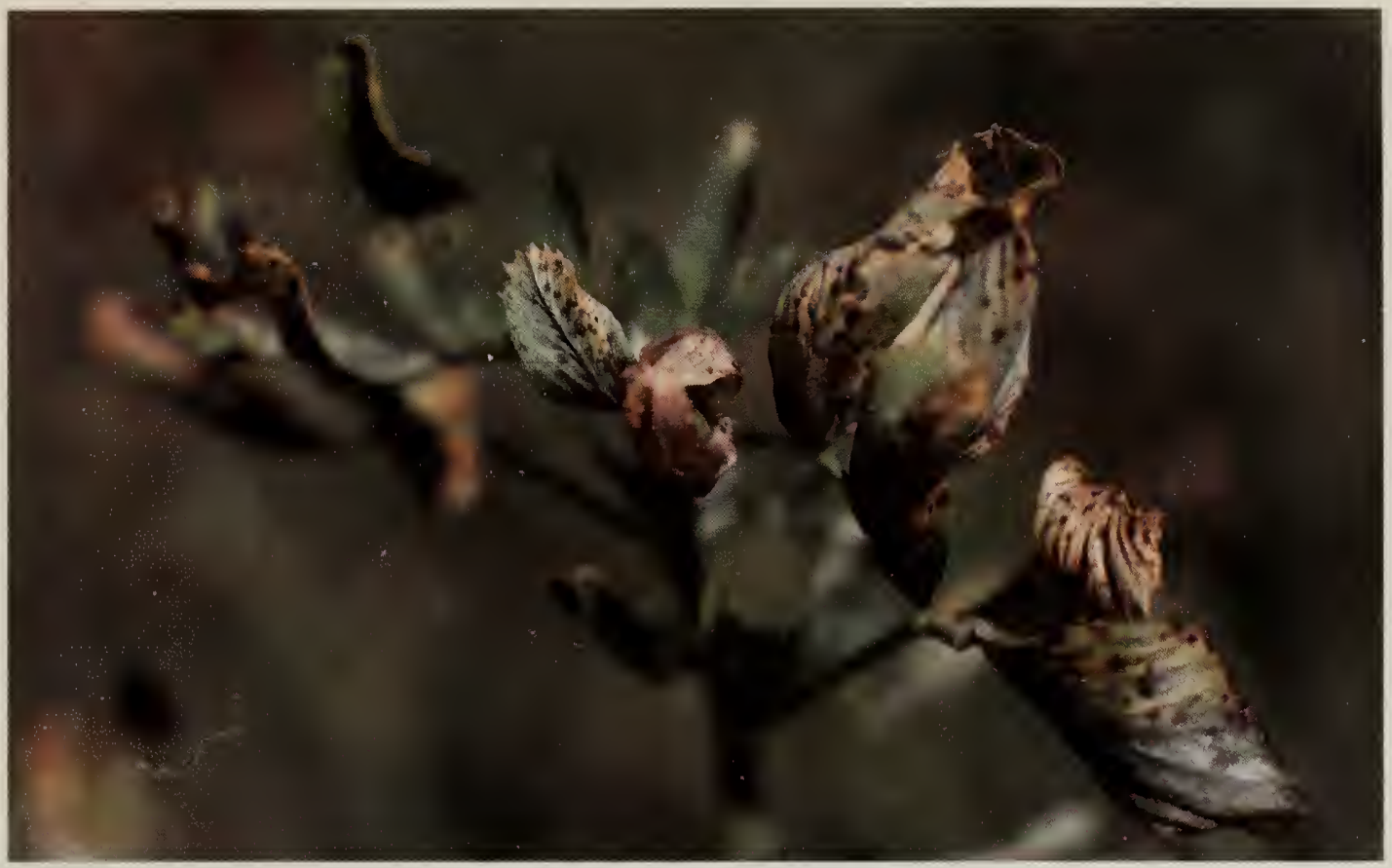

Figure 8 Common leaf spot.

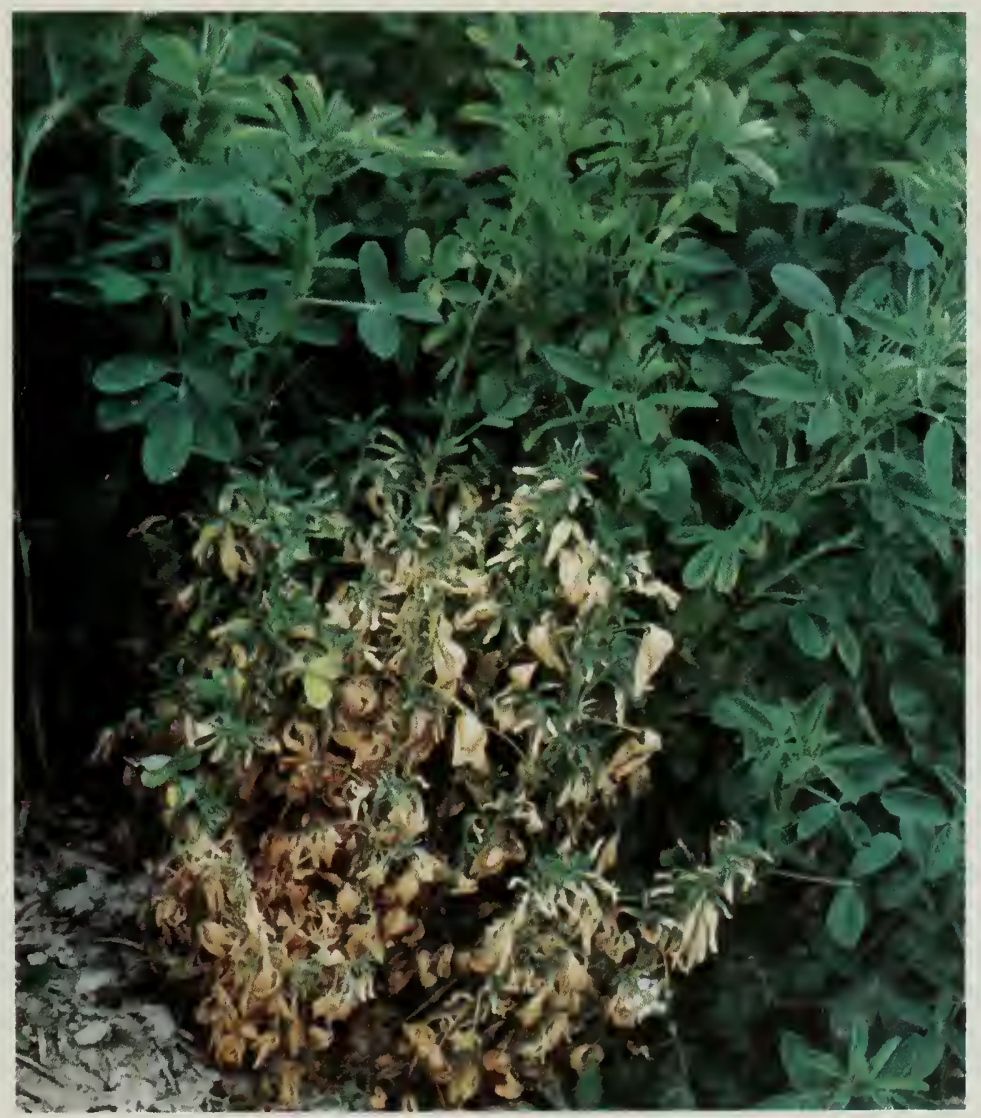

Figure 9 Verticillium wilt-stunted plant with wilted brown leaves and green-colored stems (courtesy H.C. Huang). 


\section{HARMFUL INSECTS AND NEMATODES}

Nearly 1000 species of insects and nematodes have been found to be associated with alfalfa in North America. Most of these do not directly influence alfalfa production. Some are plant feeders, some are pollinators, some are predators or parasites, many are transients, and many feed on other plants or on decaying organic matter in alfalfa fields.

Fields should be checked regularly for signs of insect or nematode damage. If damage is suspected, contact your provincial Department of Agriculture representative for advice concerning control requirements.

\section{Alfalfa weevil}

The alfalfa weevil (Fig. 10), first found in King's County, N.S. in 1981, has not been recorded in any other region in Atlantic Canada. In the spring, the adults emerge to feed on new shoots. Most damage is done in late spring and summer by the larvae, which feed inside leaf buds and which later attack the leaves. In a heavy infestation, the leaves are so badly shredded that the field appears frosted.

The adult is a brown snout beetle with a dark, V-shaped stripe along its back. The larva has a black head, yellowish-green body, and three white stripes down its back.

Harvest in the late-bud to first-bloom stage to destroy a large number of larvae before severe damage occurs. In Nova Scotia, the insect appears to be kept in check by parasites. Chemical control probably is not necessary.

\section{Alfalfa blotch leafminer}

The alfalfa blotch leafminer (Fig. 11), a relatively new pest in eastern Canada, overwinters as a pupa and emerges as a small adult fly in late May or early June. Adult feeding causes numerous pinhole punctures in leaflets into which eggs are laid, and the larvae feed between the leaf surfaces, forming irregular blotch patterns. Damage may be prevented by an early first cutting. Chemical control is usually not necessary.

\section{Pea aphid}

The pea aphid (Acyrthosiphon pisum (Harris)) is a small, green, soft-bodied insect. Large populations build up, which may cause wilting as the aphids suck juices from the leaves and stems. Damage may be reduced by early cutting. The insect has many natural enemies. 


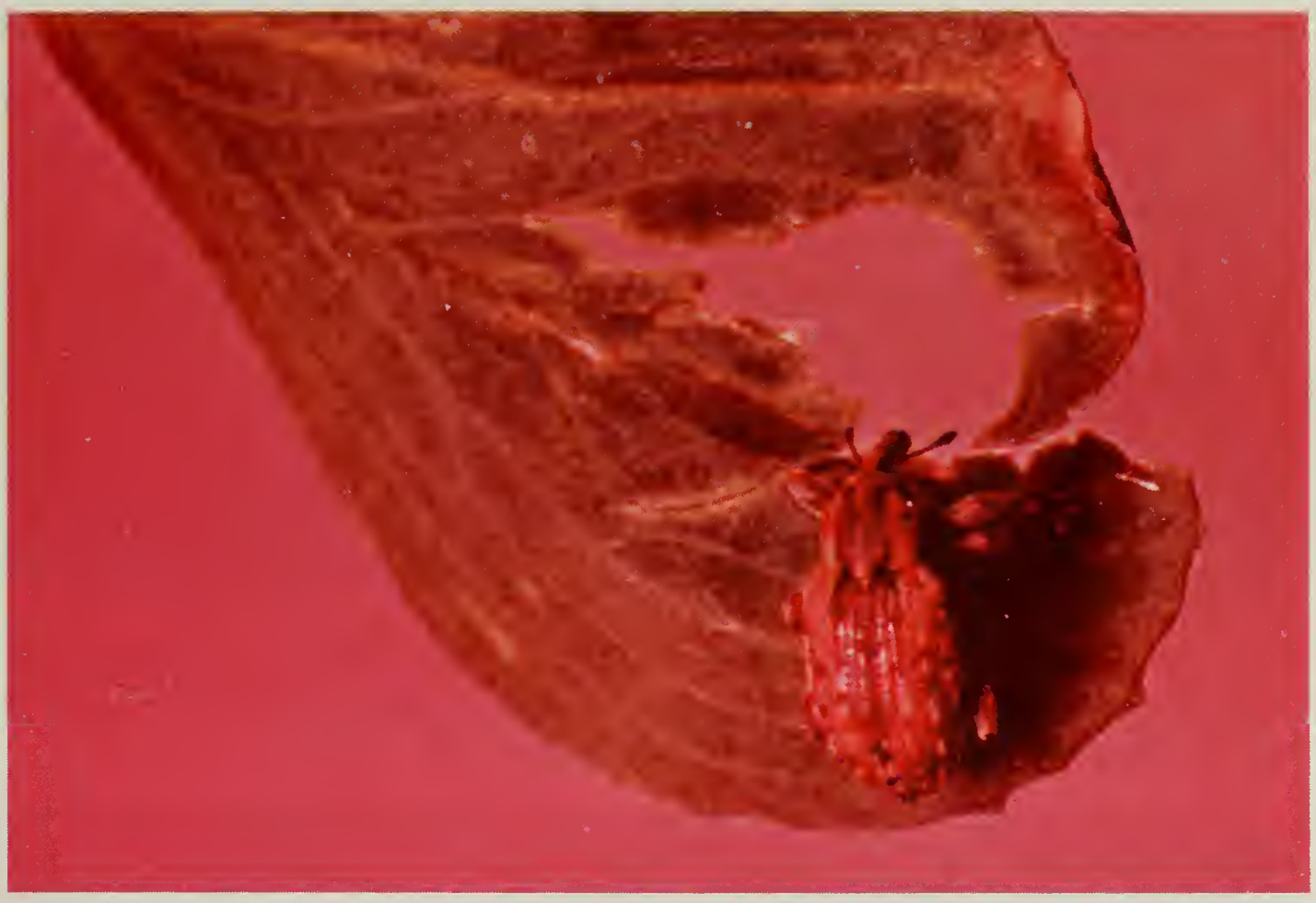

Figure 10 Alfalfa weevil, Hypera postica (Gyllenhal), adult (6 mm long).

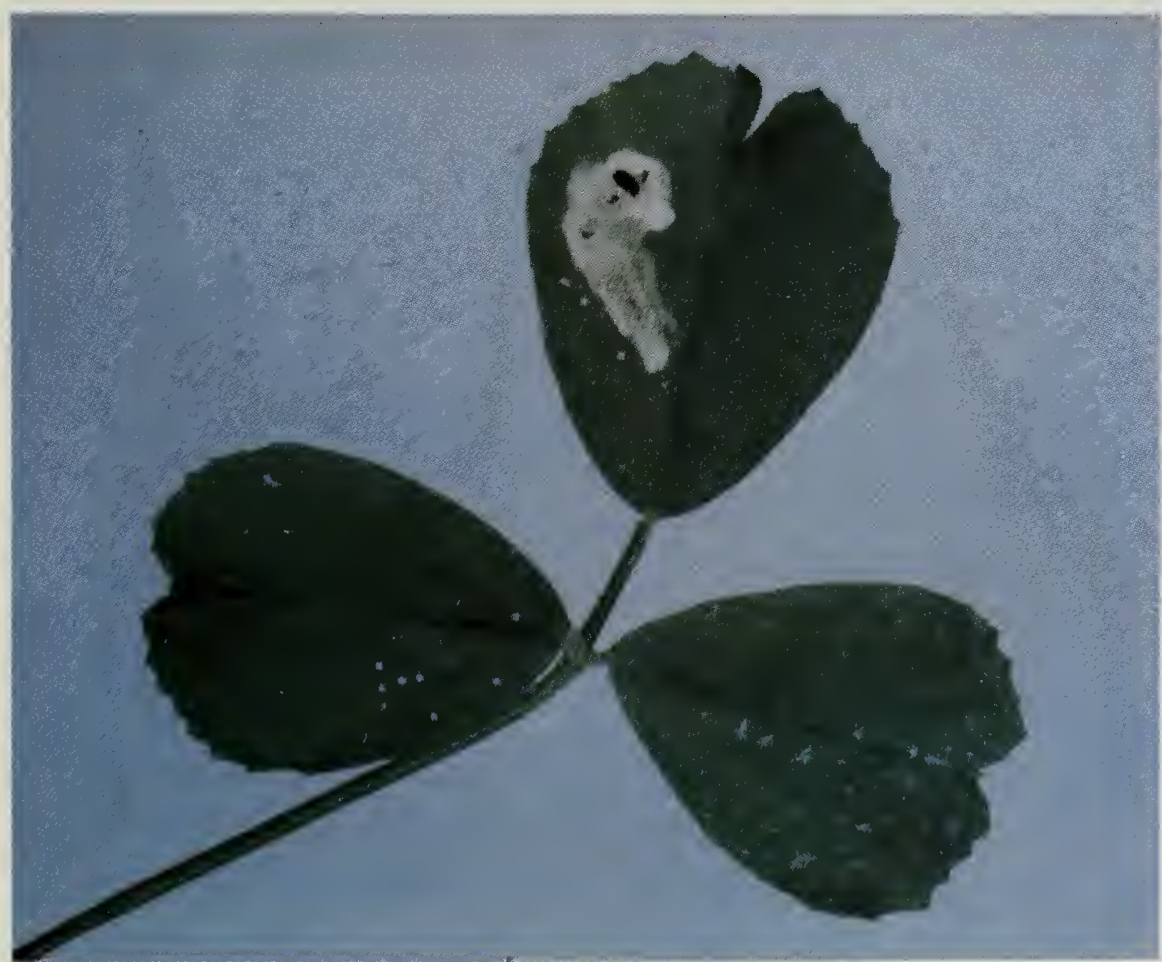

Figure 11 Blotch caused by larvae of alfalfa blotch leafminer Agromyza frontella (Rondani). Pinholes were caused by adult fly. 


\section{Clover root curculio}

The adult clover root curculio (Fig. 12) is a small, slender, dark-gray snout beetle. It feeds on the foliage but rarely causes serious damage to alfalfa. However, the larvae can cause extensive damage to the roots, particularly in older stands. Damage is characterized by extensive scarring of the epidermal layers of the roots. These lesions may become avenues of entrance for various disease pathogens causing wilt and root rot.

\section{Plant bugs}

Several species of plant bugs are common in alfalfa fields including the alfalfa and the tarnished plant bug (Fig. 13). Plant bugs suck juices from the foliage and, when abundant, their feeding may result in wilting and misshapen growing tips and buds. Control is usually not required unless alfalfa is grown for seed.

\section{Other insects}

Various other insects on occasion are pests of alfalfa including cutworms, thrips, mites, spittlebugs, leafhoppers, and webworms. Control is usually not required.

\section{Root lesion nematodes}

Several species of root lesion nematodes attack alfalfa. They invade plant roots both in the juvenile and adult stages and feed on cortical tissue. The major species in Atlantic Canada is Pratylenchus penetrans, which, when populations are large, can cause yield losses of $20 \%$ or more in alfalfa. Resistant cultivars are not yet available and nematocides are usually too expensive.

\section{Root-knot nematodes}

Root-knot nematodes invade alfalfa in every region of the world where the crop is grown. The northern root-knot nematode, Meloidogyne hapla, is the only species of root-knot nematode found in Atlantic Canada. Although M. hapla is widespread, the population levels are usually too low to cause significant damage to alfalfa.

\section{Stem nematodes}

The stem nematode, Ditylenchus dipsaci, is the most important nematode species in alfalfa on a global basis. However, the population levels are very low in Atlantic Canada, and the yield losses in alfalfa caused by this nematode species are negligible. 


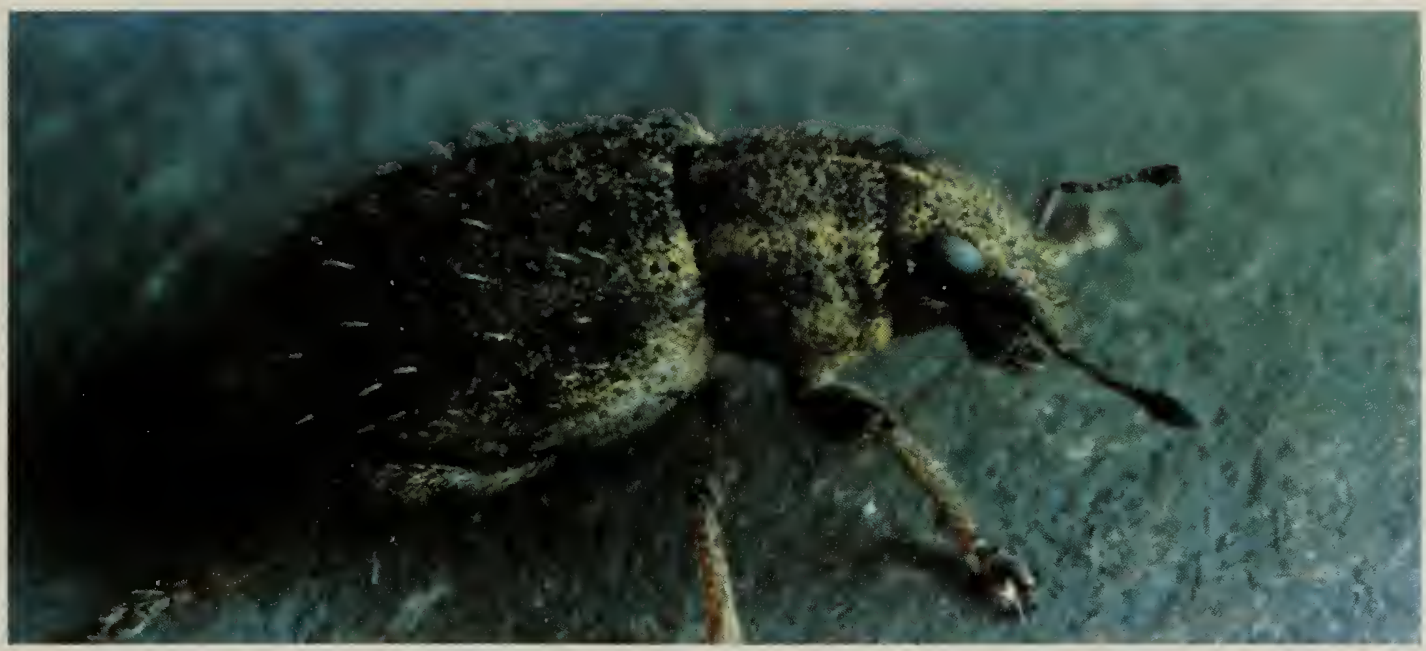

Figure 12 Clover root curculio adult ( $4 \mathrm{~mm}$ long).

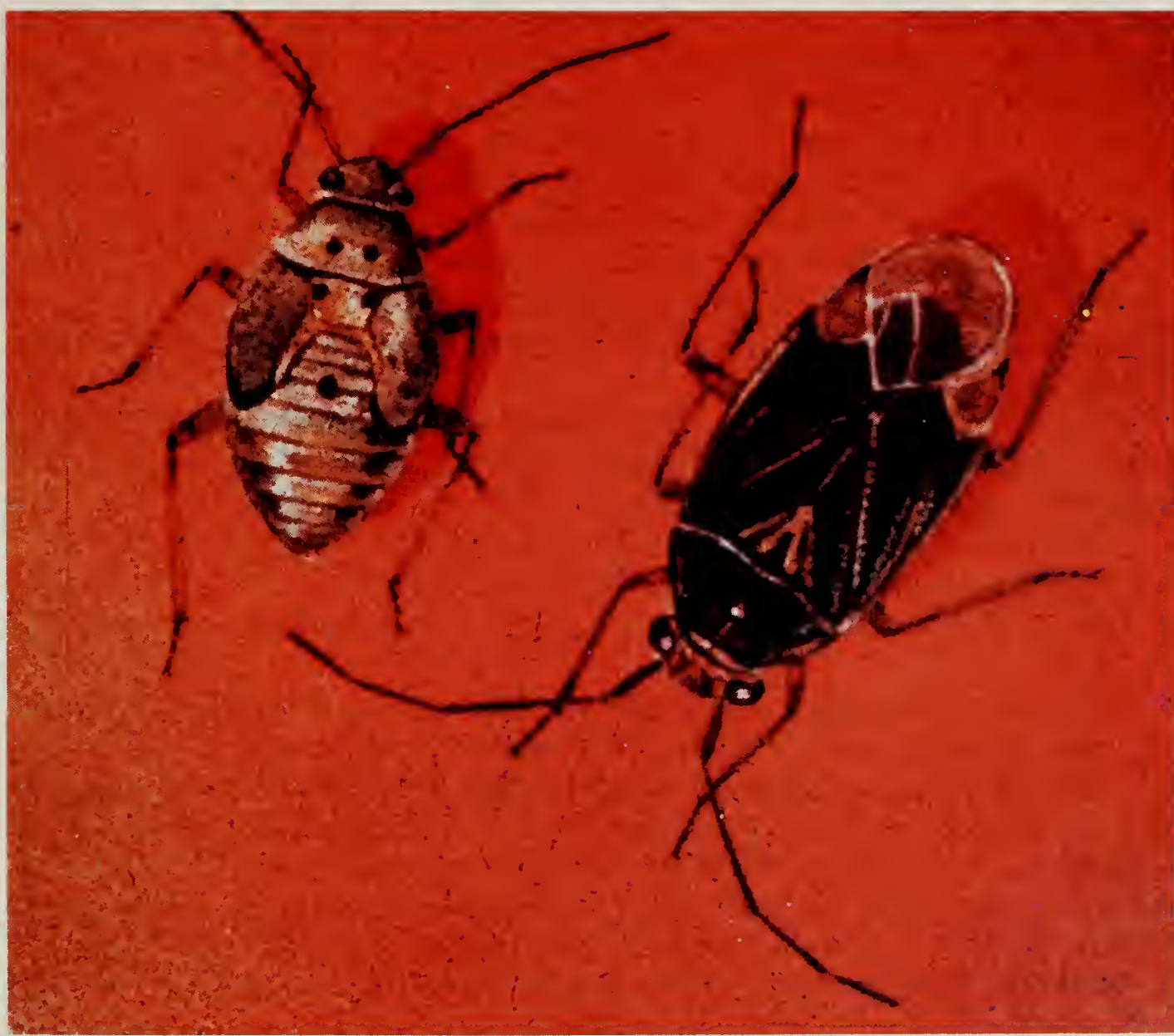

Figure 13 Tarnished plant bug nymph and adult (4 mm long). 


\section{WINTER SURVIVAL}

In Atlantic Canada, severe and extensive winter injury to alfalfa has occurred with a frequency of one in five years on average in this century. This frequency does not represent the occurrence in the last decade, as no extensive incidence has been experienced since 1978 . Nevertheless, winter climate is unpredictable and crop loss caused by winter injury is always a risk.

Of the many stress factors that affect winter survival of alfalfa, one of the most common causes of winter injury to alfalfa in Atlantic Canada is freezing temperatures immediately after midwinter thaws. Typical symptoms of the injured alfalfa are the softening and heaving of roots (Fig. 14).

The degree of cold hardiness or freezing resistance of alfalfa in Prince Edward Island increases starting from September and reaches the maximum level in late December or early January (Fig. 15). At the maximum level at least $50 \%$ of alfalfa stands can withstand $-15^{\circ} \mathrm{C}$ or $-16^{\circ} \mathrm{C}$ of crown temperature. If a midwinter thaw occurs, the high level of hardiness will suddenly drop. High temperatures and rainfalls in midwinter also result in less snow cover on the ground and exposure, waterlogging, or ice encasement of overwintering plants. Under these stressful conditions, alfalfa plants without sufficient hardiness and protection will likely sustain serious damage. This pattern is typical of winter injury to alfalfa in the region. Winter desiccation, low temperature diseases and other stress factors in winter also cause injuries, but may not cause lethal damage to alfalfa.

As midwinter thaws occur almost every year in the region, minimizing the adverse effects of these thaws is the key to the successful winter survival of alfalfa.

The risk of winter injury can be reduced by:

- selecting suitable fields (see "Field selection"),

- using well-adapted and hardy cultivars (see "Cultivar selection"), and

- applying adequate management practices to protect alfalfa stands against various environmental stresses in winter.

Adequate management practices must be started before seeding, as good establishment is a prerequisite to successful winter survival. Liming is particularly important, as a strong and well-developed root system is essential for survival. Sufficient nutrients are important, but overfertilized stands may fail to obtain high levels of hardiness.

Cutting management, particularly timing of the last cut in fall, influences the development of new buds on the crown and the quantity and quality of food reserves that are stored before winter. The number and activity of new shoots in the spring depends on the development of buds in the previous fall. Do not disturb the bud development process by cutting closely during the fall rest period (see Fig. 7). 


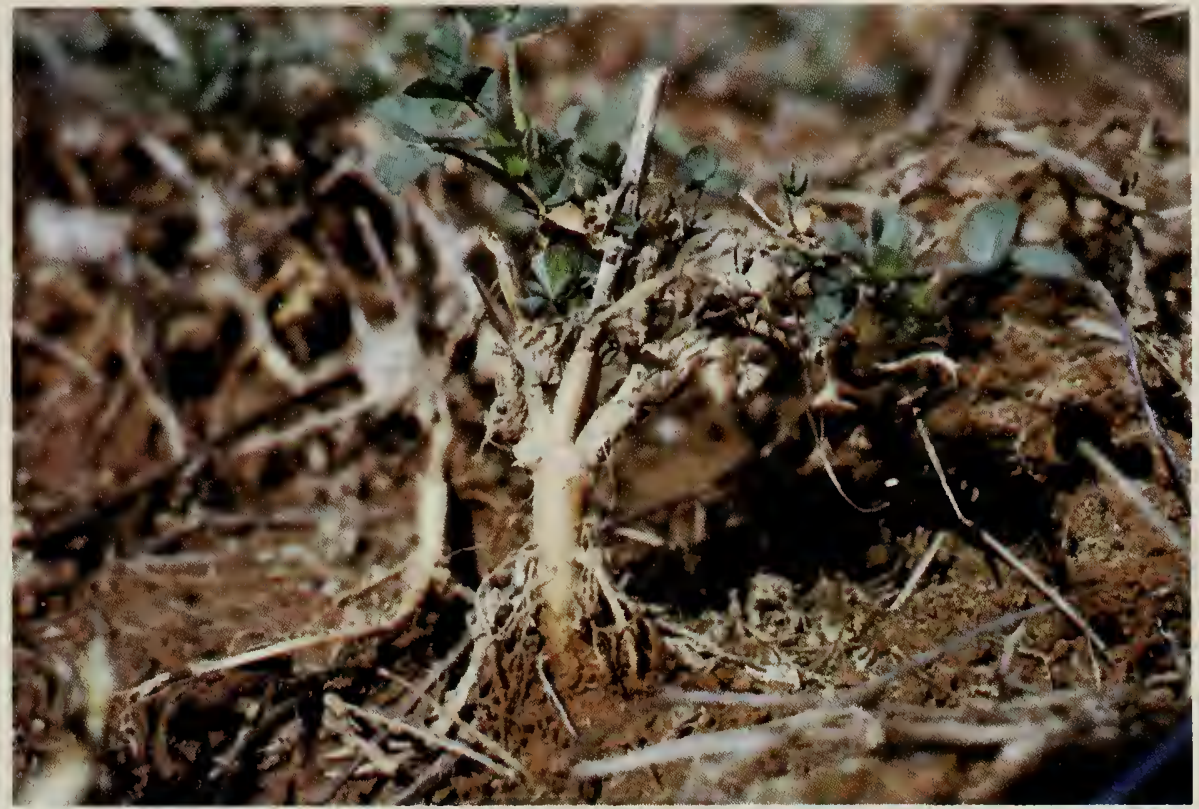

Figure 14 Frost heaving.

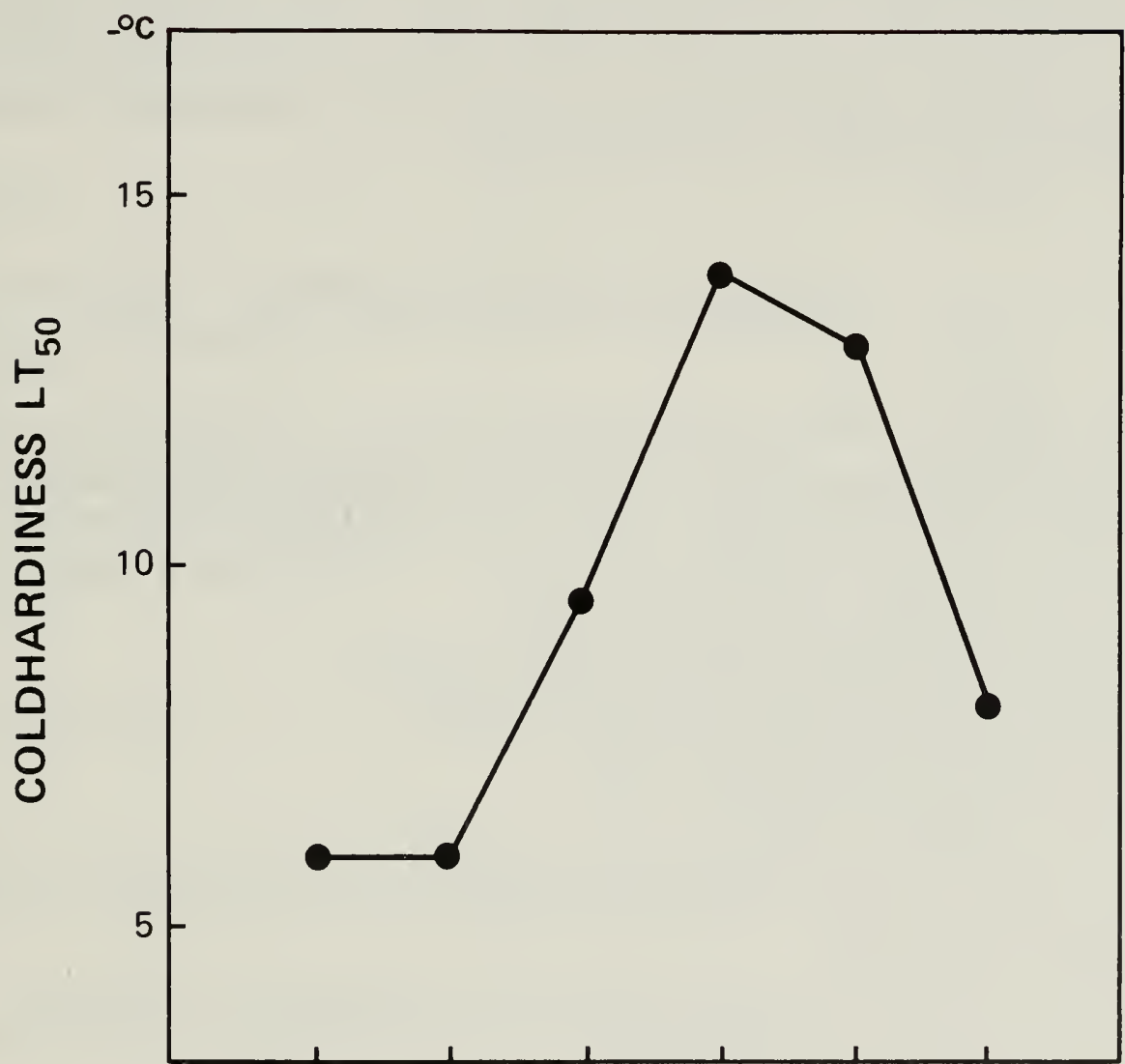

Sept.20 Oct.12 Nov.8 Dec.14 Jan.16 Feb.13

\section{DATE}

Figure 15 Seasonal changes in coldhardiness of alfalfa (means of 10 different cultivars recommended for Atlantic Canada). $\mathrm{LT}_{50}$ is the low temperature at which $50 \%$ of the plants are killed. 


\section{FEEDING TO ANIMALS}

Alfalfa, if harvested at the proper maturity and conserved carefully, contains nutritional quality nearly equivalent to that of soybean meal. High-quality alfalfa forage can reduce the cost of supplements in the diet for livestock. Forage with about $18 \%$ crude protein and $60 \%$ digestible matter can be expected to be consumed at the daily rate of $2.5-3.0 \mathrm{~kg}$ dry matter for every $100 \mathrm{~kg}$ liveweight. This amount of forage alone can maintain a $640-\mathrm{kg}$ cow at a production rate of about $20 \mathrm{~kg}$ milk daily. Alfalfa harvested at the bud stage of maturity usually contains more than $18 \%$ crude protein and less than $40 \%$ of the cell wall components (or neutral detergent fiber $=\mathrm{NDF}$ ), and about $60 \%$ of the dry matter are digestible in cattle. When feeding bud stage alfalfa with low NDF content to high-producing daily cows, it is advisable to ensure the NDF content in diet is $33 \%$ or higher to maintain a normal level of milk fat.

The bud stage alfalfa can produce more than $1 \mathrm{~kg}$ daily of liveweight in beef cattle. Alfalfa forage harvested at $10 \%$ bloom stage, containing $15 \%$ crude protein and $40-50 \% \mathrm{NDF}$, on dry basis, can be fed to mid- to late-lactating cows, nursing beef cows, and lactating ewes. More matured alfalfa, such as late cut at $50 \%$ bloom stage, is less desirable but can be used for maintaining weight of cattle and for dry stock on the dairy farm.

\section{PRODUCTION COSTS}

The cost of alfalfa production will vary from farm to farm depending on management and environmental considerations. The following cost of production estimate, is based on a conventional square-bale system (Tables 2,3 , and 4 ). In this cost analysis the following assumptions have been used:

- crop is direct seeded (Brillion-type seeder);

- alfalfa remains in the stand for 5 years;

- soil fertility is medium to high;

- initial soil pH is 6.2-6.5;

- one cut is harvested in the first year ( $2.5 \mathrm{t} / \mathrm{ha}$ of dry matter yield);

- two cuts in each remaining production year produce between 6 and $9 \mathrm{t} / \mathrm{ha}$ of hay;

- costs of alfalfa stand establishment are spread over 5 years;

- machinery costs are based on current (1987-88) custom rates and include labor costs of $\$ 7.00 / \mathrm{h}$;

- establishment and yearly production costs are expressed on a per hectare basis;

- harvesting costs are expressed on a per tonne basis based on a $19-\mathrm{kg}$ bale ( $40 \mathrm{lbs})$ at $85 \%$ dry matter; and

- production costs during years $2,3,4$, and 5 will be the same. 
Table 2 Estimates* of production and harvesting costs in seeding year

Operation

For production

Plow

37.00

Disc

20.00

Harrow

20.00

Lime $(2.5 \mathrm{t} / \mathrm{ha})$

80.00

Seeding

30.00

Fertilizer application (2x)

20.00

Fertilizer

$500 \mathrm{~kg} 5-10-30.2 \mathrm{~B}$

$200 \mathrm{~kg} \mathrm{0-0-60}$

Seed

$12 \mathrm{~kg}$ alfalfa

$4 \mathrm{~kg}$ timothy

Land rental charge

Interest (12\%)

130.00

45.00

TOTAL

586.60

For harvesting

Mower conditioner

25.00

Tedder

15.00

Rake

18.00

Bale $(\$ 0.35$ per $19 \mathrm{~kg})$

46.00

Haul/store ( $\$ 0.20$ per bale)

26.00

TOTAL

130.00

* In 1988 dollars. 
Table 3 Estimates* of production and harvesting costs in post-seeding years $2,3,4$, and 5

Operation

Costs in post-seeding years

$(\$ /$ ha/year $)$

\section{For production}

Fertilizer application $(2 \mathrm{x})$

20.00

Fertilizer

$300 \mathrm{~kg} 5-10-30.2 \mathrm{~B}$

$200 \mathrm{~kg} \mathrm{0-0-60}$

Land rental

Interest charge (12\%)

TOTAL

73.00

45.00

100.00

9.92

247.92

For harvesting

Costs for different yields ( $\$ /$ ha/year)

$6 \mathrm{t} / \mathrm{ha} \quad 7 \mathrm{t} / \mathrm{ha} \quad 8 \mathrm{t} / \mathrm{ha} \quad 9 \mathrm{t} / \mathrm{ha}$

Mower/conditioner

Tedder

Rake

Bale $(\$ 0.35 / 19 \mathrm{~kg})$

Haul/store $(\$ 0.20 /$ bale)

TOTALS

$\begin{array}{rrrr}50.00 & 50.00 & 50.00 & 50.00 \\ 30.00 & 30.00 & 30.00 & 30.00 \\ 35.00 & 35.00 & 35.00 & 35.00 \\ 111.00 & 129.00 & 147.00 & 166.00 \\ 63.00 & 74.00 & 84.00 & 95.00 \\ & & & \\ 289.00 & 318.00 & 346.00 & 376.00\end{array}$

* In 1988 dollars. 
Table 4 Summary of production and harvesting costs*

Item

Costs (\$) for different yields

$6 \mathrm{t} / \mathrm{ha} \quad 7 \mathrm{t} / \mathrm{ha} \quad 8 \mathrm{t} / \mathrm{ha} \quad 9 \mathrm{t} / \mathrm{ha}$

\begin{tabular}{lrrrr}
\hline Seeding year & & & & \\
$\quad$ Production & 586.60 & 586.60 & 586.60 & 586.60 \\
$\quad$ Harvesting & 130.00 & 130.00 & 130.00 & 130.00 \\
& & & & \\
Post-seeding year 2-5 & 991.68 & 991.68 & 991.68 & 991.68 \\
$\quad$ Production per 4 years & 1160.00 & 1272.00 & 1384.00 & 1504.00 \\
$\quad$ Harvesting per 4 years & & & & \\
& 2868.28 & 2980.28 & 3092.28 & 3212.28 \\
Total costs per hectare & $(26.50)$ & $(30.50)$ & $(34.50)$ & $(38.50)$ \\
Total yield (t/ha) & 108.24 & 97.71 & 89.63 & 83.44 \\
Total costs per tonne & 2.06 & 1.86 & 1.70 & 1.59 \\
Total costs per 19-kg bale & & & &
\end{tabular}

*In 1988 dollars.

Note: The production costs for an individual stand of alfalfa will vary greatly depending on stand longevity, yield, and other factors. This cost estimation should be used only as a guideline for calculating a producer's individual cost of production.

\section{BIBLIOGRAPHY}

Advisory Committees on Cereal, Protein, Corn and Forage Crops. 1985-1990. Field crop guide for the Atlantic provinces. Atlantic Provinces Agriculture Services Co-ordinating Committee. Publ. No. 100. Agdex No. 100.32. $52 \mathrm{p}$.

Advisory Committees on Cereal, Protein, Corn and Forage Crops. 1988. Field crop guide to variety and pesticide selection for the Atlantic provinces. Atlantic Provinces Agriculture Services Co-ordinating Committee. Publ. No. 100A. Agdex No. 100.32. $11 \mathrm{p}$.

Goplen, B.P.; Baenziger, H.; Bailey, L.D.; Gross, A.T.H.; Hanna, M.R.; Michaud, R.; Richards, K.W.; Waddington, J. 1982. Growing and managing alfalfa in Canada. Agriculture Canada Publ. 1705/E. $49 \mathrm{p}$.

Hanson, A.A.; Barnes, D.K.; Hill, R.R., editors. Alfalfa and alfalfa improvement. 1988. American Society of Agronomy. Madison, WI. Agronomy Monograph No. 29. 184 p.

MacMillan, J.; Suzuki, M. 1987. Soil capability map for forage legume production in the Maritime provinces. Agriculture Canada, Ottawa, Ont. Canadex 524-125.

Martens, J.W.; Seaman, W.L.; Atkinson, T.G., editors. 1984. Diseases of field crops in Canada: An illustrated compendium. Canadian Phytopathological Society. $160 \mathrm{p}$.

Minister of Agriculture and Food, Ontario. 1989. Guide to weed control. Publ. No. 75. Agdex No. 641. 



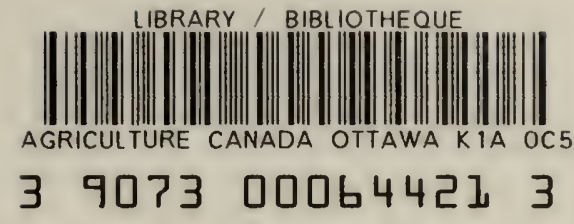


